\title{
Assessment of Undiscovered Continuous Oil and Gas Resources in the Dnieper-Donets Basin and North Carpathian Basin Provinces, Ukraine, Romania, Moldova, and Poland, 2015
}

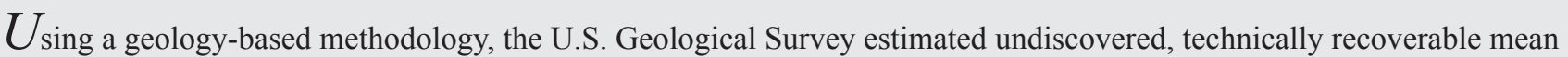
resources of 13 million barrels of oil and 2,643 billion cubic feet of natural gas in the Dnieper-Donets Basin and North Carpathian Basin Provinces of Ukraine, Romania, Moldova, and Poland.

\section{Introduction}

The U.S. Geological Survey (USGS) completed an assessment of continuous (unconventional) oil and gas resources in geologic provinces of Ukraine, Romania, Moldova, and part of Poland (fig. 1). The areas and resources that were evaluated and assessed included Paleozoic shale gas and tight-sandstone gas in the DnieperDonets Basin Province in Ukraine, continuous oil in the Oligocene Menilite Shale of the North Carpathian Basin Province of Ukraine (however, parts in some areas can be as young as lower Miocene [Koltun and others, 1998; Pawlewicz, 2006]), and lower Paleozoic (mainly Silurian) shale gas that extends across several geologic provinces of Ukraine, Romania, Moldova, and a small part of Poland.

In the Dnieper-Donets Basin Province, two total petroleum systems (TPSs) were identified: (1) a Paleozoic Composite TPS containing the Carboniferous Tight Sandstone Gas AU and (2) the Carboniferous Rudov Bed TPS containing the Carboniferous Rudov Bed Shale Gas AU. In the North Carpathian Basin Province and neighboring geologic provinces, a Paleozoic Composite TPS and an Oligocene Menilite Shale TPS were identified. This TPS contains the East European Lower Paleozoic Shale Gas $\mathrm{AU}$, which includes mainly Silurian mudstones and some Ordovician mudstones. An Oligocene Menilite Shale TPS and corresponding Oligocene Menilite Shale Continuous Oil AU were also delineated.

The USGS assessment methodology for continuous resources outside of the United States requires that potential source rocks in the AU meet certain criteria, including the following: (1) contain at least 2 weight percent or more total organic carbon; (2) contain Type I, Type II, or Type IIS kerogen; (3) are thermally mature to generate oil and natural gas; and (4) contain organic-rich shale greater than 15 meters in thickness (Charpentier and Cook, 2011). All four continuous TPSs meet these geologic criteria. Analogs for shalegas, continuous oil, and tight-sandstone gas accumulations in the United States were used to quantitatively assess the AUs in this study. Specifically, mean estimated ultimate recoveries from populations of shale-gas, continuous oil, and tight-sandstone gas wells; mean drainage areas of drilled wells; and ranges of average well success ratios were used to estimate the undiscovered continuous oil and gas resources. Principal input data used in the assessment are listed in table 1.

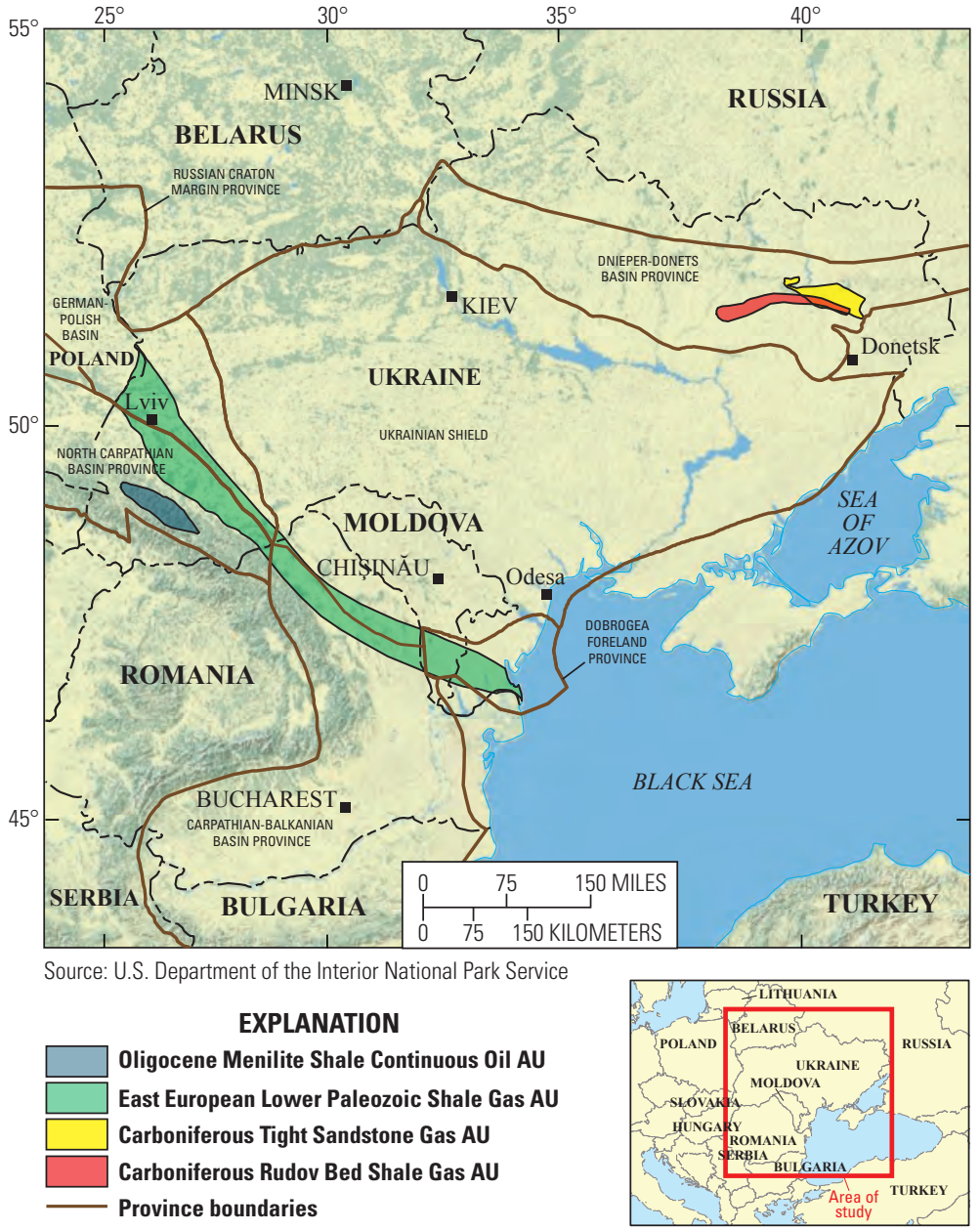

Figure 1. Map showing locations of continuous oil and gas assessment unit (AU) boundaries in Ukraine, Romania, Moldova, and Poland.

\section{Undiscovered Resources Summary}

The USGS quantitatively assessed oil and gas resources in three continuous gas AUs and one continuous oil AU within the Dnieper-Donets Basin and North Carpathian Basin Provinces of Ukraine, Romania, Moldova, and Poland (table 2). For total undiscovered resources, the estimated means are 13 million barrels of continuous oil (MMBO) with an F95-F5 range from 3 to $29 \mathrm{MMBO}, 2,643$ billion cubic feet of natural gas (BCFG) with an F95-F5 range from 8 to 8,487 BCFG, and 37 million barrels of natural gas liquids (MMBNGL) with an F95-F5 range from 0 to 123 MMBNGL. For 
gas accumulations, zeros at F95 reflect the chance that continuous gas might not exist in the AU, and the geologic AU probability (risk) was estimated to be less than one.

For continuous gas resources in the Dnieper-Donets Basin Province, the estimated means for the Carboniferous Tight Sandstone Gas AU are 590 BCFG with an F95-F5 range from 0 to $1,771 \mathrm{BCFG}$ and 12 MMBNGL with an F95-F5 range from
0 to 36 MMBNGL. For continuous shalegas resources, the estimated means for the Carboniferous Rudov Bed Shale Gas AU are 624 BCFG with an F95-F5 range from 0 to 1,984 BCFG and 12 MMBNGL with an F95-F5 range from 0 to 41 MMBNGL.

For continuous resources in the North Carpathian Basin Province, the estimated means for the East European Lower Paleozoic Shale Gas AU are 1,391 BCFG with an F95-F5 range from 0 to 4,642 BCFG and 11 MMBNGL with an F95-F5 range from 0 to 40 MMBNGL. The estimated means for the Oligocene Menilite Shale Continuous Oil AU are 13 MMBO with an F95-F5 range from 3 to $29 \mathrm{MMBO}, 38 \mathrm{BCFG}$ with an F95-F5 range from 8 to $90 \mathrm{BCFG}$, and 2 MMBNGL with an F95-F5 range from 0 to 6 MMBNGL.

Table 1. Key assessment input data for the four continuous assessment units in the Dnieper-Donets Basin Province and the North Carpathian Basin Province.

[AU, assessment unit; \%, percent; EUR, estimated ultimate recovery per well; BCFG, billion cubic feet of gas; MMBO, million barrels of oil. EUR, well drainage area, and success ratios are from U.S. shale-gas, continuous oil, and tight-sandstone gas analogs. The average EUR input is the minimum, median, maximum, and calculated mean. Shading indicates not applicable]

\begin{tabular}{|c|c|c|c|c|c|c|c|c|}
\hline \multirow{2}{*}{$\begin{array}{l}\text { Assessment input data- } \\
\text { Continuous AU }\end{array}$} & \multicolumn{4}{|c|}{ Carboniferous Tight Sandstone Gas AU } & \multicolumn{4}{|c|}{ Carboniferous Rudov Bed Shale Gas AU } \\
\hline & Minimum & Mode & Maximum & Calculated mean & Minimum & Mode & Maximum & Calculated mean \\
\hline Potential production area of AU (acres) & 5,000 & 100,000 & 710,000 & 271,667 & 5,000 & 100,000 & 690,000 & 265,000 \\
\hline Average drainage area of wells (acres) & 60 & 90 & 150 & 100 & 80 & 100 & 140 & 107 \\
\hline Success ratios $(\%)$ & 10 & 50 & 90 & 50 & 10 & 50 & 90 & 50 \\
\hline Average EUR (BCFG) & 0.1 & 0.5 & 1.4 & 0.544 & 0.1 & 0.7 & 1.3 & 0.72 \\
\hline \multirow{3}{*}{ AU probability } & 0.8 & & & & 0.7 & & & \\
\hline & \multicolumn{4}{|c|}{ Oligocene Menilite Shale Continuous Oil AU } & \multicolumn{4}{|c|}{ East European Lower Paleozoic Shale Gas AU } \\
\hline & Minimum & Mode & Maximum & $\begin{array}{c}\text { Calculated } \\
\text { mean }\end{array}$ & Minimum & Mode & Maximum & Calculated mean \\
\hline Potential production area of AU (acres) & 1,000 & 75,000 & 190,000 & 88,667 & 5,000 & $1,000,000$ & $9,470,000$ & $3,491,667$ \\
\hline Average drainage area of wells (acres) & 200 & 250 & 350 & 267 & 120 & 160 & 200 & 160 \\
\hline Success ratios $(\%)$ & 10 & 50 & 90 & 50 & 10 & 50 & 90 & 50 \\
\hline Average EUR (MMBO, oil; BCFG, gas) & 0.04 & 0.07 & 0.2 & 0.077 & 0.1 & 0.15 & 0.8 & 0.185 \\
\hline AU probability & 1.0 & & & & 0.7 & & & \\
\hline
\end{tabular}

Table 2. Assessment results for the four continuous assessment units in the Dnieper-Donets Basin Province and the North Carpathian Basin Province.

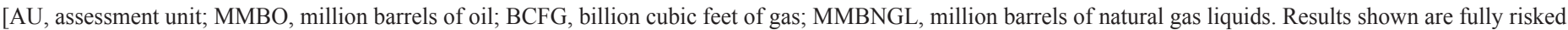

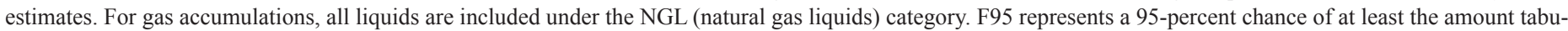
lated. Other fractiles are defined similarly. Fractiles are additive under the assumption of perfect positive correlation. Shading indicates not applicable]

\begin{tabular}{|c|c|c|c|c|c|c|c|c|c|c|c|c|c|c|}
\hline \multirow{3}{*}{$\begin{array}{l}\text { Total petroleum systems } \\
\text { and assessment units (AUs) }\end{array}$} & \multirow{3}{*}{$\begin{array}{c}\text { AU } \\
\text { prob- } \\
\text { ability }\end{array}$} & \multirow{3}{*}{$\begin{array}{c}\text { Accu- } \\
\text { mulation } \\
\text { type }\end{array}$} & \multicolumn{12}{|c|}{ Total undiscovered resources } \\
\hline & & & \multicolumn{4}{|c|}{ Oil (MMBO) } & \multicolumn{4}{|c|}{ Gas (BCFG) } & \multicolumn{4}{|c|}{ NGL (MMBNGL) } \\
\hline & & & F95 & F50 & F5 & Mean & F95 & F50 & F5 & Mean & F95 & F50 & F5 & Mean \\
\hline \multicolumn{15}{|c|}{ Dnieper-Donets Basin Province } \\
\hline \multicolumn{15}{|c|}{ Paleozoic Composite Total Petroleum System } \\
\hline Carboniferous Tight Sandstone Gas AU & 0.8 & Gas & & & & & 0 & 434 & 1,771 & 590 & 0 & 8 & 36 & 12 \\
\hline \multicolumn{15}{|c|}{ Carboniferous Rudov Bed Total Petroleum System } \\
\hline Carboniferous Rudov Bed Shale Gas AU & 0.7 & Gas & & & & & 0 & 444 & 1,984 & 624 & 0 & 9 & 41 & 12 \\
\hline \multicolumn{15}{|c|}{ North Carpathian Basin Province } \\
\hline \multicolumn{15}{|c|}{ Paleozoic Composite Total Petroleum System } \\
\hline East European Lower Paleozoic Shale Gas AU & 0.7 & Gas & & & & & 0 & 853 & 4,642 & 1,391 & 0 & 6 & 40 & 11 \\
\hline \multicolumn{15}{|c|}{ Oligocene Menilite Shale Total Petroleum System } \\
\hline Oligocene Menilite Shale Continuous Oil AU & 1.0 & Oil & 3 & 11 & 29 & 13 & 8 & 32 & 90 & 38 & 0 & 2 & 6 & 2 \\
\hline Total continuous resources & & & 3 & 11 & 29 & 13 & 8 & 1,763 & 8,487 & 2,643 & 0 & 25 & 123 & 37 \\
\hline
\end{tabular}

\section{References Cited}

Charpentier, R.R., and Cook, T.A., 2011, USGS methodology for assessing continuous petroleum resources: U.S. Geological Survey Open-File Report 2011-1167, 73 p., accessed September 26, 2016, at at http://pubs.usgs.gov/of/2011/1167/.

Koltun, Yu., Espitalié, J., Kotarba, M., Roure, F., Ellouz, N., and Kosakowski, P., 1998, Petroleum generation in the Ukrainian External Carpathians and the adjacent foreland: Journal of Petroleum Geology, v. 21, no. 3, p. 265-288.

Pawlewicz, Mark, 2006, Total petroleum systems of the North Carpathian Province of Poland, Ukraine, Czech Republic, and Austria: U.S. Geological Survey Bulletin 2204-D, 26 p.

\section{Ukraine Assessment Team}

Timothy R. Klett, Christopher J. Schenk, Michael E. Brownfield, Ronald R. Charpentier, Tracey J. Mercier, Heidi M. Leathers-Miller, and Marilyn E. Tennyson

\section{For More Information}

Assessment results are available at the USGS Energy Resources Program Web site at http://energy.usgs.gov/. 